\title{
Fifty cases of human immunodeficiency virus (HIV) infection: immunoultrastructural study of circulating lymphocytes
}

\author{
W W FEREMANS, * K HUYGEN, ${ }^{*}$ R MENU, ${ }^{*}$ C M FARBER, $\dagger$ J P DE CALUWE, \\ J P VAN VOOREN, $\ddagger$ L MARCELIS, $₫$ L ANDRE,§ M BRASSEUR,§ H BONDUE, $\dagger+$ \\ B LEBON, * N CLUMECK**
}

From the * Laboratory of Pathology and Electron Microscopy, Free University of Brussels, $\uparrow$ Pasteur Institute of Brabant, $\ddagger$ Cliniques Universitaires Hôpital Erasme, ††Institut Medico-chirugie Ixelles, \Clinique Parc Leopold, $\S$ Centre Hospitalier Joseph Bracops, and the **Department of Infectious Diseases, Saint-Pierre Hospital, Brussels, Belgium

SUMMARY The peripheral lymphocytes of 50 cases of human immunodeficiency virus (HIV) $\stackrel{\circ}{\rightarrow}$ infection (13 of acquired immune deficiency syndrome (AIDS), 17 of AIDS related complex (ARC), and 20 healthy carriers) were studied immunoultrastructurally. The prevalence of "tubuloreticular structures" and "tubular confronting cisternae" increased with the progression of the disease. Numerous tubular confronting cisternae were noted in patients presenting with a high serum acid labile $\alpha$-interferon values. The patients with depressed natural killer cell activity were characterised by circulating immature natural killer cells with abundant multivesicular bodies that were devoid of "parallel tubular arrays". With an immunogold staining technique the location of HIV antigen was detected ultrastructurally, both at the surface of "hand-mirror" natural killer cell lymphocytes and inside vacuolised cells, probably corresponding to infected T4 lymphocytes. These findings indicate the usefulness of electron microscopic techniques in evaluating the pathology and the pathogenetic outcome of AIDS.

The existence of ultrastructural markers was first reported in patients with "full-blown" acquired immune deficiency syndrome (AIDS).' We have described similar findings in cases of AIDS from Central Africa. ${ }^{2}$ Only a few well documented ultrastructural studies on peripheral lymphocytes in AIDS and AIDS related complex (ARC) have been carried out. ${ }^{3-5} \mathrm{We}$ previously showed the presence of retroviral antigens by immunogold staining in circulating lymphocytes in prodromal AIDS. ${ }^{6}$ This study aimed to describe and complement our description by investigating the clinical importance of the ultrastructural abnormalities observed in peripheral blood lymphocytes through different clinical stages of human immunodeficiency virus (HIV) infection. Colloidal gold antibody probes were applied for the identification of the membrane phenotype of the abnormal cells and for detecting the ultrastructural location of HIV antigen.

Accepted for publication 5 August 1987

\section{Material and methods}

Diagnosis of HIV infection was based on positive HIV serology (ELAVIA, with additional uninfected $\mathrm{H} 9$ controls), a low T4:T8 ratio or a positive HIV core 3 . antigen detected by a solid phase radioimmunoassay ${ }^{7} \delta$ on cultured peripheral lymphocytes, or a combination. All cases with positive serology (ELAVIA) but $ᄋ$ with a T4:T8 ratio of $>1$ were confirmed to be positive for IgG antibodies by Western blot analysis or radioimmunoprecipitation. The classification of $\frac{N}{N}$ ("full-blown") AIDS, ARC, and healthy carriers was o made according to the United States criteria of the $N$ Center for Disease Control, Atlanta. ${ }^{89}$ AIDS was $\underset{\mathrm{N}}{\mathrm{N}}$ detected in 13, ARC in 17 patients, and 20 were healthy controls. There were 22 women and 28 men. High risk groups included 11 homosexuals, 25 central Africans, seven heterosexual patients who had had sex $\stackrel{\oplus}{+}$ with an infected partner, one European missionary 0 living in Zaire, three drug addicts, two Haitians, and ${ }^{\circ}$ one European who had a blood transfusion in Haiti $\stackrel{\odot}{\stackrel{D}{ }}$ four years ago. Of those with AIDS, one had Kaposi's $\stackrel{\vec{\mathbb{}}}{\mathbb{Q}}$ 
sarcoma alone and one Kaposi's sarcoma associated with opportunistic infection. The average T4:T8 ratios were 0.24 for the AIDS, 0.34 for ARC, and 1.13 for healthy controls.

Polyclonal hypergammaglobulinaemia was detected in $83 \%$ of patients with AIDS, $94 \%$ of those with ARC, and in $35 \%$ of healthy controls. Serum $\beta$-2-microglobulin (Pharmacia radioimmunoassay) was consistently raised above $3.5 \mathrm{mg} / \mathrm{l}$ in $75 \%$ of AIDS patients, $38 \%$ of those with ARC, and in $22 \%$ of healthy controls. The simultaneous presence of HIV antibodies and HIV antigens was shown in all the AIDS patients, $75 \%$ of those with ARC, and in $35 \%$ of healthy controls. The presence of antibodies against HIV without antigen detection was not found in any patients with AIDS, but was present in $25 \%$ of patients with ARC, and in $25 \%$ of healthy controls. The detection of antigen alone, noted exclusively in $40 \%$ of healthy controls, was striking. The determination of serum acid labile $\alpha$-interferon concentration was performed as previously described by Huygen et al. ${ }^{10}$ The percentage of circulating large granular lymphocytes and their natural killer function were evaluated by cytofluorimetric analysis (EPICS) with Leu7 and NKH1 monoclonal antibodies, and the release of ${ }^{51} \mathrm{Cr}$ against $\mathrm{K}-562$ cells, respectively. The ability of total blood cells to produce $\alpha$ and $\gamma$-interferon was assayed according to the method described by Kirchner." Interleukin-2 production isolated by purified lymphocytes was also Ficoll-Hypaque evaluated.

\section{ULTRASTRUCTURAL STUDY}

Peripheral mononuclear cells isolated by FicollHypaque gradient (Lymphoprep) were rapidly fixed for 30 minutes at room temperature by a solution of $4 \%$ glutaraldehyde, buffered by $0.1 \mathrm{M}$ phosphate, at $\mathrm{pH} 7 \cdot 4 .^{12}$ The cells washed in the same buffer were fixed with $2 \%$ phosphate buffered osmium tetroxide and were dehydrated by graded concentrations of ethanol. The material was embedded in Epon ${ }^{13}$ and sectioned by a Diatome diamond knife with an LKB Ultratome $\mathrm{V}$ microtome. Ultrathin sections stained with uranyl acetate and lead citrate were observed with a Siemens Elmiskop electron microscope. After embedding, the circulating lymphocytes, which had been fixed by $2 \%$ glutaraldehyde buffered by $0 \cdot 1 \mathrm{M}$ sodium cacodylate $(\mathrm{pH} \mathrm{7.6)}$ for a period of two hours at room temperature, were stained with immunogold. Postfixation was omitted. Ultrathin sections on nickel grids were then incubated as previously described. ${ }^{6}$ This postembedding method was performed for the detection of intracytoplasmic HIV antigen using a rabbit polyclonal antiserum against the p13 core protein of lymphadenopathic virus (LAV) (gift from the Pasteur Institute, Paris). The specificity of this antiserum was established by control experiments performed on HIV infected and non-infected $\mathrm{H} 9$ cells (gift from the laboratory of Dr RC Gallo, United States National Cancer Institute, Bethesda). Positive immunogold staining was observed only in HIV infected H9 cells.

The pre-embedding immunogold staining method ${ }^{6}$ was used for the identification of HIV antigen on the cellular membrane with the same anti-LAV antiserum and for the determination of the membrane phenotype of the cell with a set of the following monoclonal antibodies: OKT4, OKT8 and anti-HLA DR (Ortho), NKH1 (Coulter), and Leu7 (Becton-Dickinson).

\section{Results}

A network of branched tubules of 20 to $25 \mathrm{~nm}$ called "tubuloreticular structures" (fig 1) was located in the rough and smooth endoplasmic reticulum, in the perinuclear cisterna (rarely), or in the Golgi apparatus. Tubuloreticular structures were seen in all the subpopulations of the circulating mononuclear

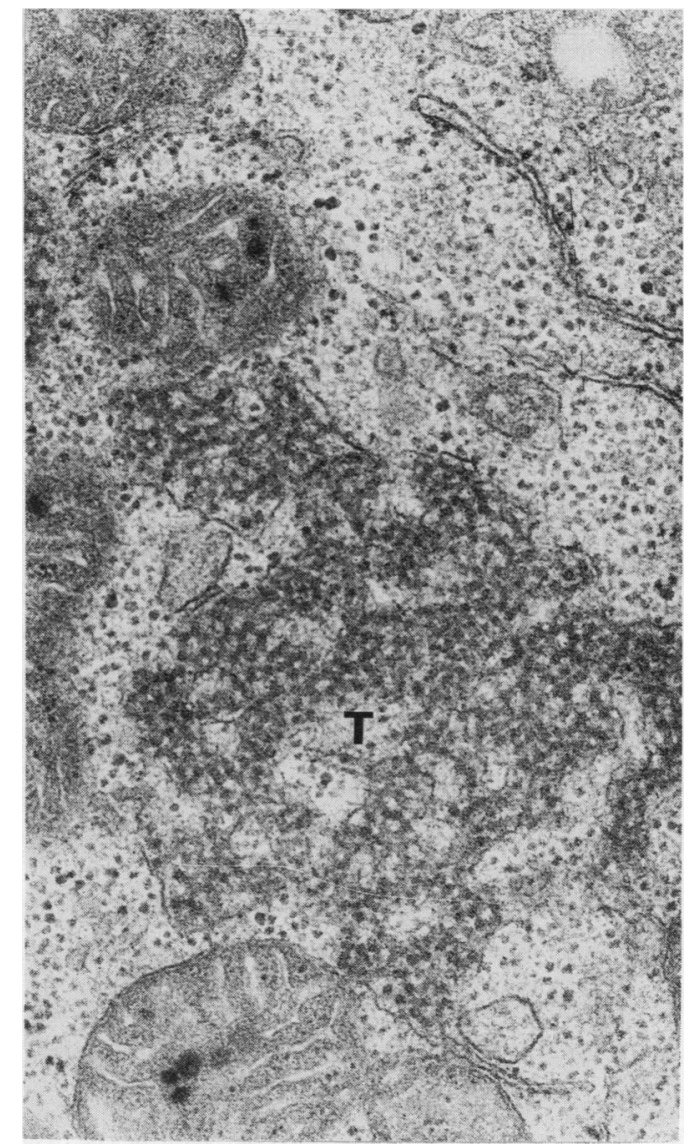

Fig 1 "Tubuloreticular structure" (T) of a lymphocyte. 
64 Feremans, Huygen, Menu, Farber, de Caluwe, van Vooren, Marcelis, Andre, Brasseur, Bondue, Lebon, Clumeck cells including monocytes. They were predominant in the $\mathrm{OKT} 8$ positive and the $\mathrm{NKH} 1$ positive phenotypes (fig 2). Tubuloreticular structures were observed in 13 of 13 patients with AIDS, 11 of 17 patients with ARC $(64 \%)$, and in only two of 20 healthy controls $(10 \%)$. The average T4:T8 ratio was 0.25 among the patients with tubuloreticular structures and 1.13 in those without tubuloreticular structures.

Serum acid labile $\alpha$-interferon concentration was above $10 \mathrm{U} / \mathrm{ml}$ (normal value <6) in 11 of $15(73 \%)$ patients with tubuloreticular structures and in two of $10(20 \%)$ of the patients without: one of these last two patients had recently seroconverted at the time of writing.

"Tubular confronting cisternae"14 appeared in longitudinal view as cylinders ranging between 1.5 to $2.5 \mu \mathrm{m}$ in length and about $300 \mathrm{~nm}$ in width. In cross sectional aspect they comprised two concentric cisternae with an electron dense layer of about $25 \mathrm{~nm}$ between them (fig 3). Tubuloreticular structure were sometimes visible inside tubular confronting cisternae (fig 4). Tubular confronting cisternae were also detected in all the subpopulations of the circulating mononuclear cells. We observed tubular confronting cisternae in six of 13 patients with AIDS (46\%), five of

17 patients with ARC (29\%), and in one of 20 healthy controls $(5 \%)$ : this last was the only healthy control to have progressed to AIDS during the year of follow up. Tubular confronting cisternae were never shown in the absence of tubuloreticular structures. The average T4:T8 ratio of the patients with tubular confronting cisternae was $0 \cdot 21$. Serum acid labile $\alpha$-interferon concentration was raised in four of five patients positive for tubular confronting cisternae. Three of these four had the highest values of $\alpha$-interferon observed in our study-28, 56, and $70 \mathrm{U} / \mathrm{ml}$, respectively.

Circulating plasma cells were observed with HLA DR positive phenotype and often showed abnormal mitochondria (fig 5). These cytological characteristics were shown in $57 \%$ of our patients and were associated with a polyclonal hypergammaglobulinaemia in $91 \%$ of these cases.

In two patients "hand-mirror" cells with an eccentric nucleus and a cytoplasmic uropod bristling with microspikes were noticed (fig 6). After immunogold staining the membrane phenotype of these hand mirror cell disclosed their likely natural killer nature (fig 2). Moreover, a characteristic immunogold staining of the tip of their uropod (fig 7) was observed after

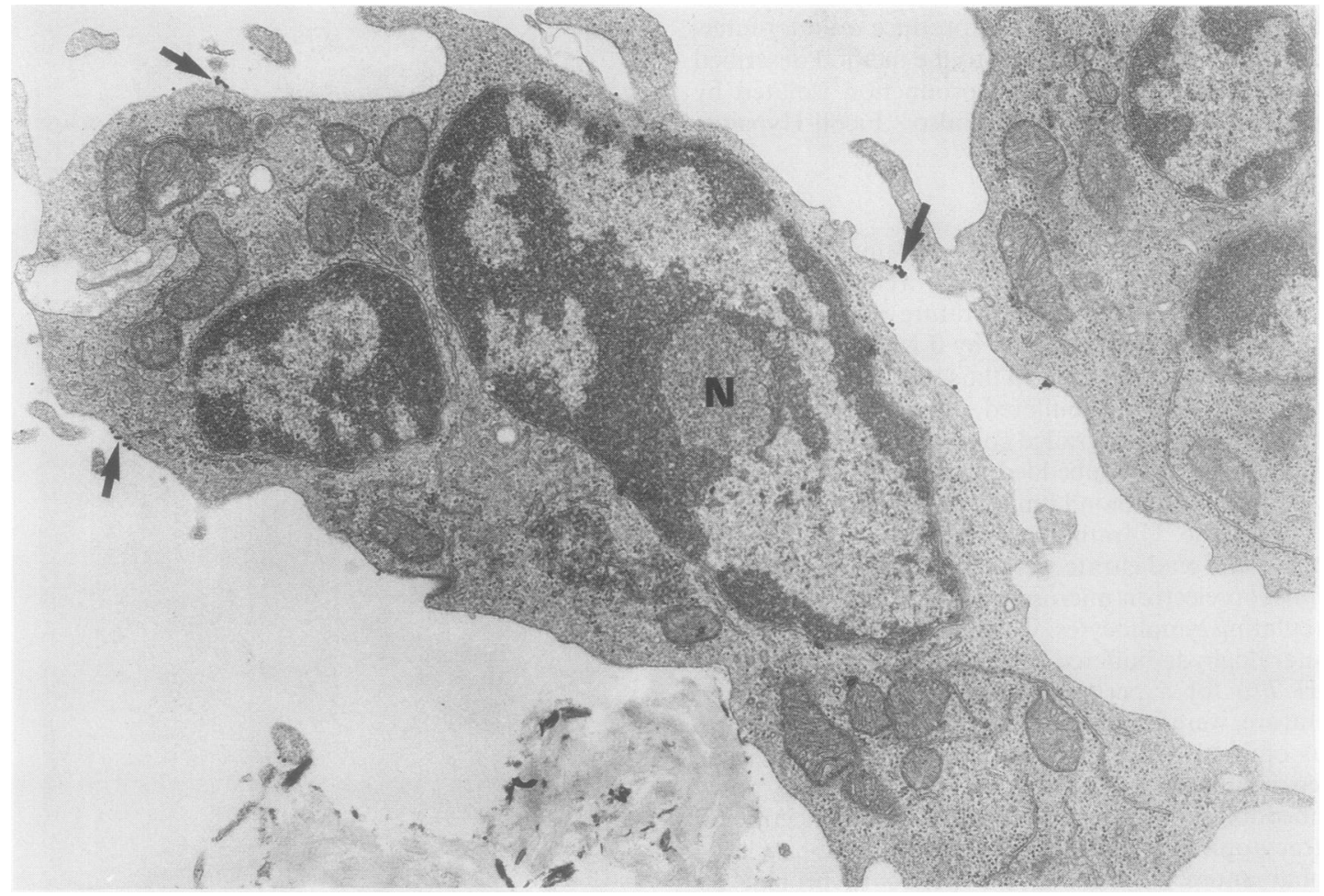

Fig 2 "Tubuloreticular structure" ( $T)$ of a natural killer cell of amoeboid configuration. Cellular membrane is stained $(\rightarrow)$ with immunogold with NKHI monoclonal antiserum. $N=$ nucleus. 


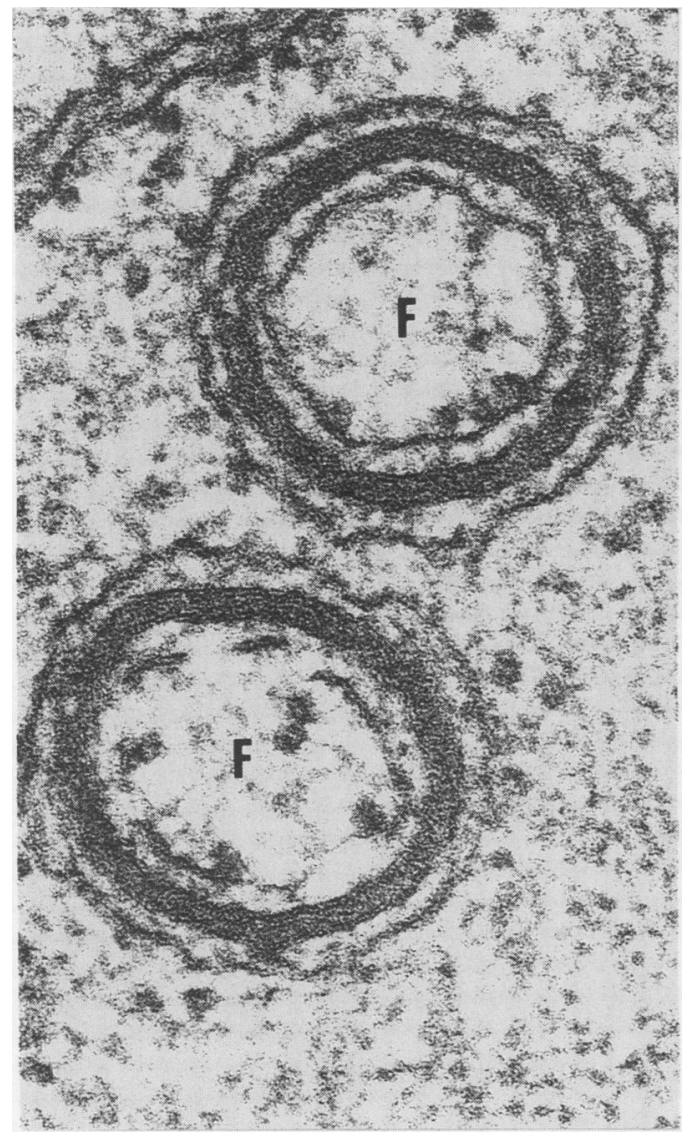

Fig 3 Cross sectional aspect of "tubular confronting cisternae" $(F)$.

incubation with the antiserum directed against LAV. Control experiments with a normal rabbit serum and a monoclonal antibody against baboon endogenous virus (BaEV) gave negative results.

The cytofluorimetric analysis (EPICS) of the purified Ficoll-Hypaque lymphocytes disclosed a normal number of positive cells for the Leu7 and NKH1 phenotypes in all nine cases tested (table). Whatever the clinical stage and concentrations of $\alpha$ interferon, $\gamma$-interferon, or interleukin- 2 productions, four of these nine patients had depressed natural killer cell activity. Patients with a normal natural killer cell function against K562 target cells had about $10 \%$ of lymphocytes containing the typical "parallel tubular arrays," which were recognised as the ultrastructural marker of natural killer cell lymphocytes (fig 8). By contrast, patients with a depressed natural killer cell function were identified by the absence of parallel tubular arrays and the presence of about $10 \%$ of lymphocytes with numerous cytoplasmic multivesicular bodies (fig 9).
A striking finding was that in two thirds of the 50 cases about $1 \%$ of large multinucleated circulating cells were observed. Their cytoplasm showed cytoplasmic vacuoles, ranging from 0.8 to $1.5 \mu \mathrm{m}$ in average diameter, and containing a granular material with occasional double outlined vesicles (fig 10). These cells did not display the ultrastructural appearance of monocytes, usually recognisable by their typical granules with a clear peripheral halo. Moreover, these vacuolated cells were neither found in the purified population of non-rosetting cells (B lymphocytes and monocytes) nor in the purified preparation of OKT8 positive cells that we have previously described. ${ }^{6}$ An immunospecific reactivity with a polyclonal antiserum directed against the principal core protein p24 of the bovine leukaemia virus was also localised in these vacuoles. ${ }^{6}$ Similar positive staining was obtained using the polyclonal antiserum directed against LAV in four of four cases of AIDS, one of two cases of ARC, and one of eight healthy controls. Vacuoles containing retroviral core proteins were also observed in fetal lamb kidney cells, in MT2 cells, and in H9 cells infected by BLV, HTLV I, and HTLV III, respectively. To identify the membrane phenotype of these vacuolated circulating cells pre-embedding immunogold staining with anti-HLA DR, OKT4, OKT8, NKH1, and Leu7 monoclonal antibodies was performed. Surprisingly, all of these monoclonal antibodies were unreactive. After a similar experiment performed on cultured peripheral lymphocytes, infected by HIV, we observed a strong membrane reactivity with the OKT8 antiserum in lymphocytes

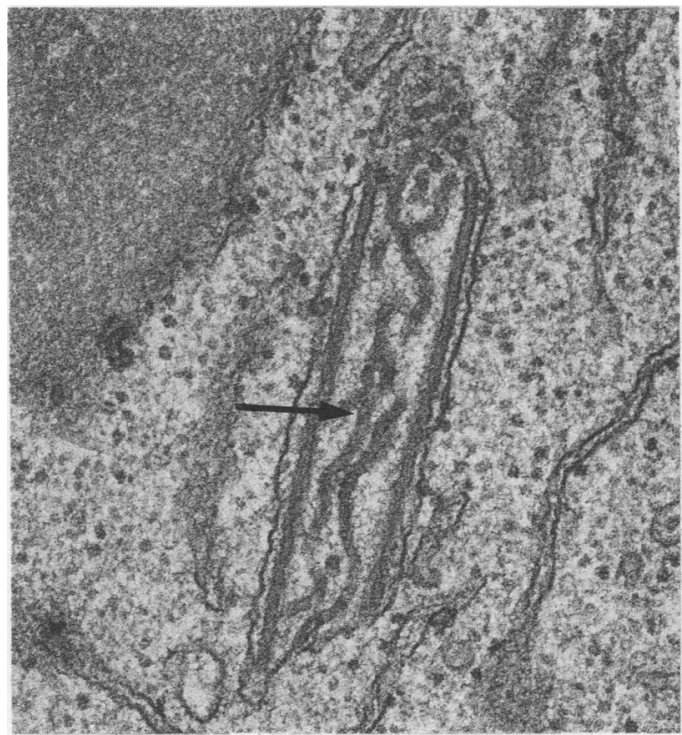

Fig 4 "Tubuloreticular structure" $(\rightarrow)$ inside "tubular confronting cisternae". 


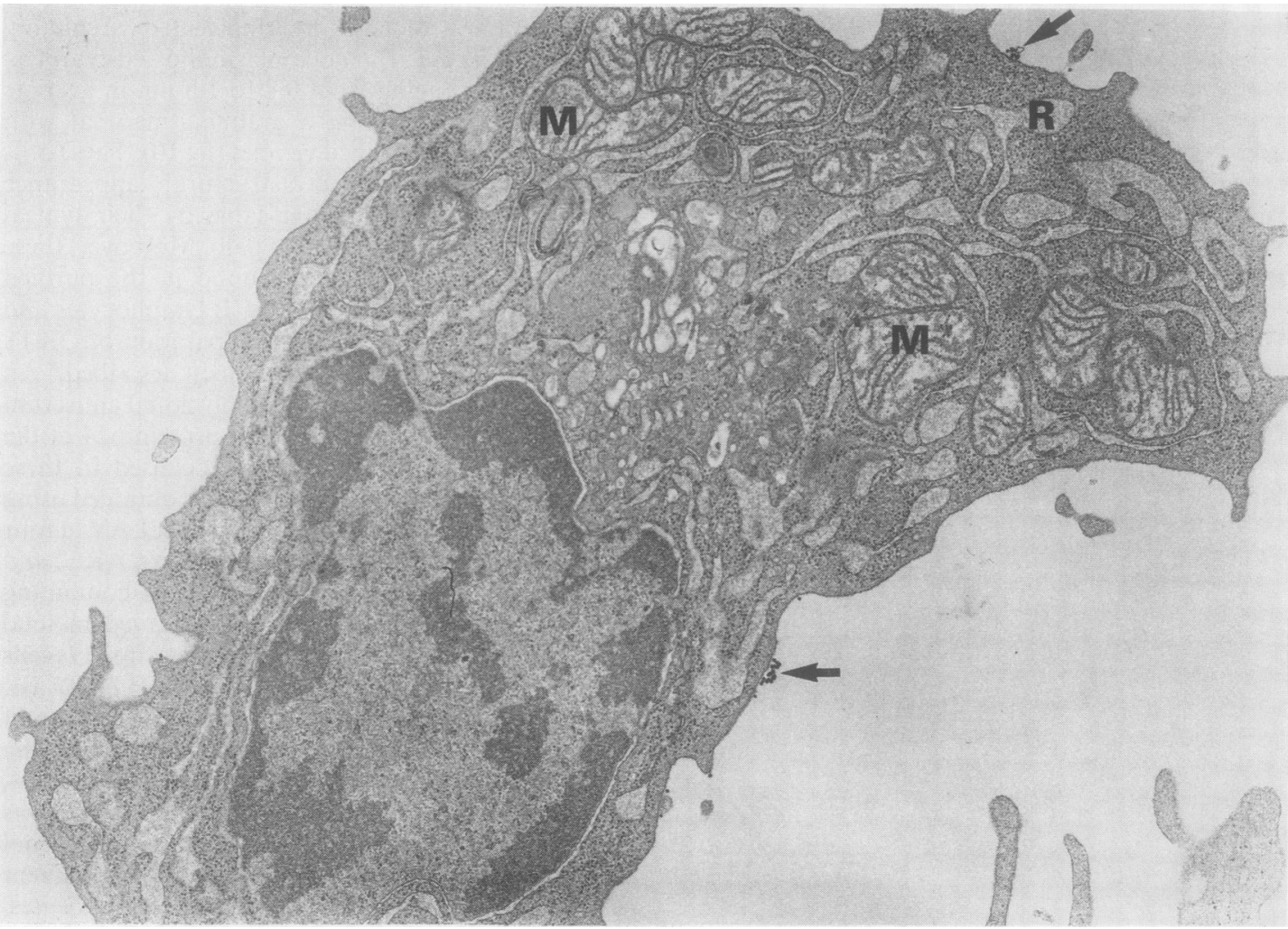

Fig 5-Circulating plasmatocyte stained $(\rightarrow)$ by immunogold with anti-HLA DR monoclonal antibody. $M=$ mitochondria; $R=$ rough endoplasmic reticulum.

that had not been infected with HIV. By contrast, the membrane of the lymphocytes actively producing HIV particles did not react with OKT8 or OKT4 monoclonal antibodies.

\section{Discussion}

"Tubuloreticular structures" and "Tubular confronting cisternae" are not specific for AIDS or ARC, but, nevertheless, they have not been reported in healthy homosexuals. ${ }^{4}$ Systemic lupus erythematosus, ${ }^{15}$ herpes simplex encephalitis, ${ }^{16}$ congenital rubella, ${ }^{17}$ cytomegalovirus pneumonia, ${ }^{18}$ simian non-A non-B hepatitis, ${ }^{19}$ and miscellaneous malignant disease ${ }^{2021}$ are the other principal conditions in which tubuloreticular structures have been found. Tubuloreticular structures can also be generated in cell culture by $\alpha$ and $\beta$ interferon but not by $\gamma$-interferon. ${ }^{22-24}$ Moreover,

Table Analysis of natural killer population

\begin{tabular}{|c|c|c|c|c|c|c|c|c|c|}
\hline $\begin{array}{l}\text { No } \\
\text { of cases }\end{array}$ & $T 4: T 8$ & $N K H I$ & $\begin{array}{l}\text { Natural } \\
\text { killer function }\end{array}$ & $\alpha$ interferon & $\gamma$ interferon & ILL2 & Stage & $P T A$ & $M V B$ \\
\hline $\begin{array}{l}24 \\
25 \\
28 \\
31 \\
32 \\
33 \\
39 \\
43 \\
45\end{array}$ & $\begin{array}{l}0.3 \\
0.3 \\
0.2 \\
0.6 \\
0.2 \\
0.7 \\
0.9 \\
0.6 \\
0.3\end{array}$ & $\begin{array}{l}\mathbf{N} \\
\mathbf{N} \\
\mathbf{N} \\
\mathbf{N} \\
\mathbf{N} \\
\mathbf{N} \\
\mathbf{N} \\
\mathbf{N} \\
\mathbf{N}\end{array}$ & $\begin{array}{l}< \\
\mathbf{N} \\
\mathbf{N} \\
< \\
\mathbf{N} \\
\mathbf{N} \\
< \\
< \\
\mathbf{N}\end{array}$ & $\begin{array}{l}< \\
\mathbf{N} \\
< \\
\mathbf{N} \\
< \\
< \\
< \\
< \\
<\end{array}$ & $\begin{array}{l}\mathbf{N} \\
\mathbf{N} \\
\mathbf{N} \\
\mathbf{N} \\
\mathbf{N} \\
< \\
\mathbf{N} \\
\mathbf{N} \\
\mathbf{N}\end{array}$ & $\begin{array}{l}< \\
< \\
< \\
\mathbf{N} \\
< \\
\mathbf{N} \\
\mathbf{N} \\
\mathbf{N} \\
\mathbf{N}\end{array}$ & $\begin{array}{l}\text { ARC } \\
\text { HC } \\
\text { AIDS } \\
\text { HC } \\
\text { HC } \\
\text { HC } \\
\text { HC } \\
\text { ARC } \\
\text { ARC }\end{array}$ & $\begin{array}{l}\overline{+} \\
+ \\
\overline{+} \\
+ \\
- \\
- \\
+\end{array}$ & $\begin{array}{l}+ \\
- \\
- \\
+ \\
- \\
- \\
+ \\
+ \\
-\end{array}$ \\
\hline
\end{tabular}

NKH1 = monoclonal antibody against natural killer cells; $f$ NK $=$ natural killer function; IL2 $=$ interleukin-2; PTA $=$ parallel tubular arrays; $\mathrm{MVB}=$ multivesicular bodies. 


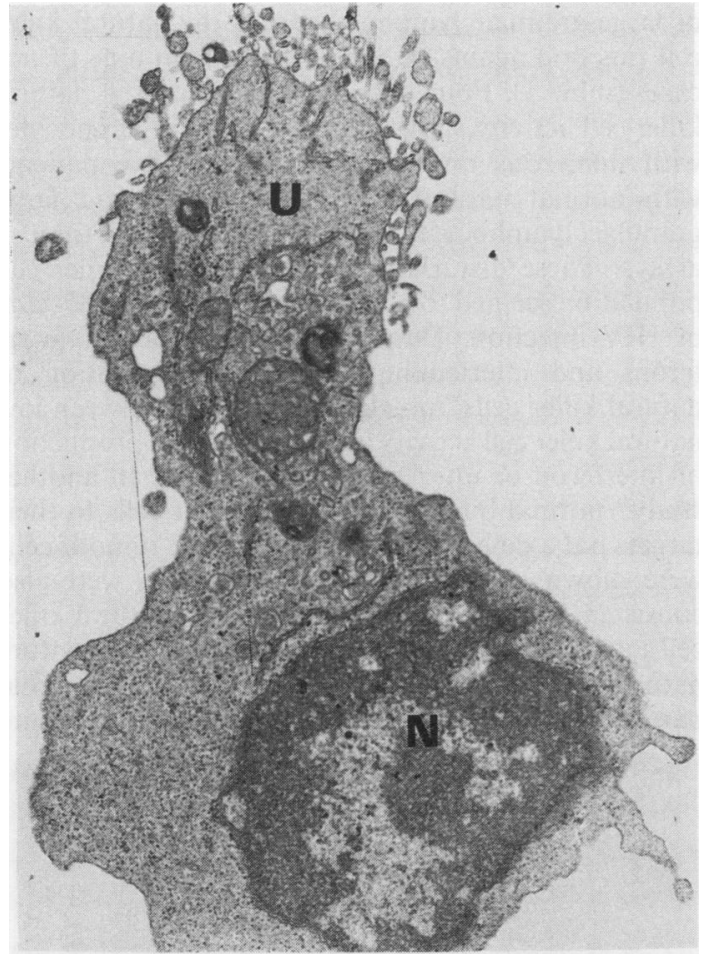

Fig 6 "Hand mirror" lymphocyte. $N=$ nucleus; $U=$ uropod.

systemic treatment with $\alpha$-interferon induced the appearance of tubuloreticular structures in circulating mononuclear cells. ${ }^{25}$ AIDS and systemic lupus erythematosus have a clinical common denominator -the presence in the serum of an unusual acid labile $\alpha$ interferon. ${ }^{26}{ }^{27}$ In the present study we noticed the simultaneous occurrence of tubuloreticular structures and acid labile $\alpha$-interferon in $73 \%$ of the patients examined.

"Tubular confronting cisternae", ${ }^{14}$ referred to also as "test-tube and ring-shaped forms",' have a lower prevalence in HIV infection than tubuloreticular structures. They have rarely been reported elsewhere: in sporadic cases of simian non-A non-B hepatitis, ${ }^{28}$ HTLV-I related leukaemia ${ }^{29}$ multiple sclerosis, ${ }^{30}$ and collagen diseases. ${ }^{31}$ The generation of tubular confronting cisternae in vitro and in vivo by $\alpha$-interferon has not yet been confirmed. Tubular confronting cisternae, however, have never been detected in the absence of tubuloreticular structures, and both structures were closely connected in the lymphocytes of some of the aforementioned patients (fig 4). Moreover, the highest values of acid labile $\alpha$-interferon in our study occurred in patients with tubular confronting cisternae. The prevalence of tubuloreticular structures and tubular confronting cisternae seemed to be related to the progression of the disease, according to the studies of Sidhu ${ }^{4}$ and Orenstein. ${ }^{5}$ Interestingly, the presence of serum acid labile $\alpha$-interferon in patients with ARC was also reported as a prognostic marker for progression to AIDS. ${ }^{10}$ With Orenstein, ${ }^{5}$ we consider that a particularly poor prognosis was associated with the detection of tubular confronting cisternae. This assumption should be further verified through prospective study.

Circulating plasma cells displayed an immature phenotype (HLA DR positive) and showed several ultrastructural features of myeloma cells, especially the presence of elongated mitochondria with poorly developed cristae in a clear matrix. Circulating plasma cells were associated with polyclonal hypergammaglobulinaemia in $91 \%$ of our cases. This finding is characteristic of the chronic stimulation, principally by HIV and EBV, of the B cell lineage. ${ }^{32} 33$

"Hand-mirror cells" were first described by Lewis. ${ }^{34}$

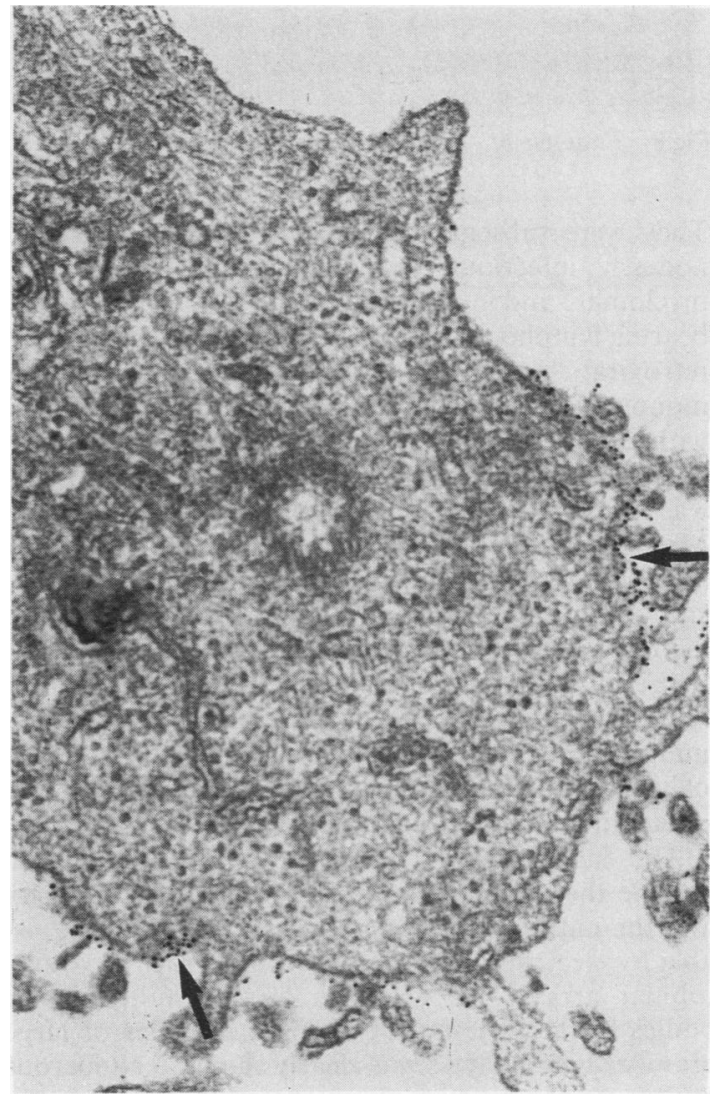

Fig 7 Cell surface at tip of the uropod stained $(\rightarrow)$ by pre-embedding immunogold staining technique using $a$ polyclonal antiserum against $L A V$. 


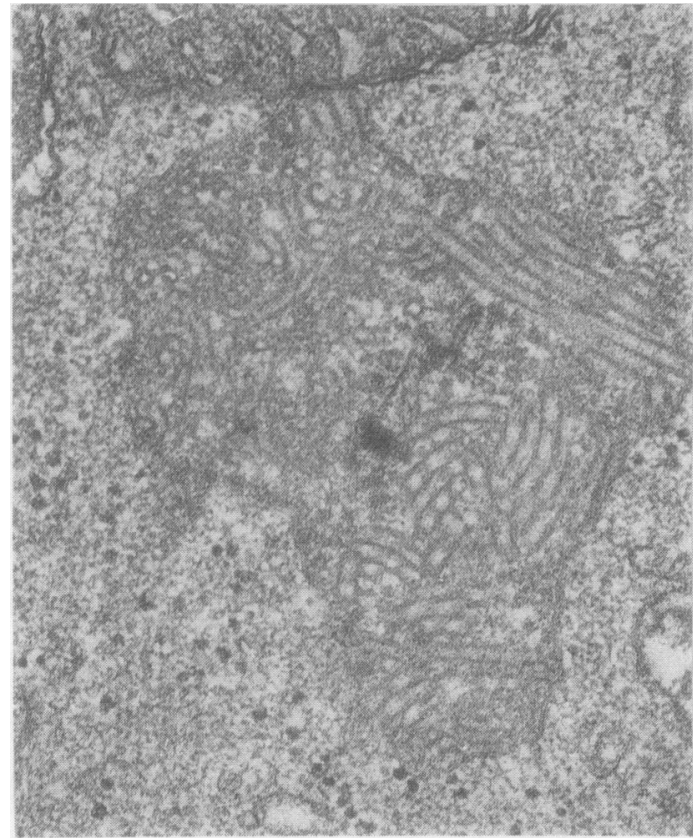

Fig 8 Example of "parallel tubular arrays" inclusion.

They were subsequently reported in normal lymph nodes, ${ }^{35}$ infectious mononucleosis, ${ }^{36}$ lymphoma, ${ }^{37}$ myeloma,${ }^{38}$ and in acute leukaemia. ${ }^{38-40}$ These uropodbearing lymphocytes might be induced by virus ${ }^{41}$ or by retroviral antigens, or both. ${ }^{4243}$ In infectious mononucleosis the demonstration of hand mirror cell with parallel tubular arrays ${ }^{44}$ and their lytic activity against $B$ lymphocytes infected by Epstein-Barr virus ${ }^{45}$ was consistent with their natural killer phenotype. Moreover, uropod-bearing cells were often found among the large granular lymphocytes. ${ }^{46}$ In the present study the pre-embedding immunogold staining method showed a NKH1-positive membrane phenotype and LAV antigenic sites at the tip of the uropod. Hand mirror cells were also observed by Sidhu in HIV infection. ${ }^{4} \mathrm{He}$ described an electrodense layer at the tip of the uropod, probably corresponding to adsorbed circulating immune complexes.

The large granular lymphocytes (LGL), which assume the antibody dependent cellular cytotoxicity and the natural killer function, were easily recognisable by electron microscopy owing to their "parallel tubular arrays" 478 The role of the multivesicular bodies in the genesis of the dense granules of large granular lymphocytes was clearly shown..$^{49}$ Numerous multivesicular bodies were observed in immature forms of large granular lymphocytes devoid of natural killer cell function. We attempted to verify this association between the ultrastructural characteristics of large granular lymphocytes and the natural killer cell function against K562 target cells in nine of our cases (table 1). Four patients with depressed natural killer cell activity showed large granular lymphocytes with numerous multivesicular bodies, five patients with normal natural killer cell activity had large granular lymphocytes with typical parallel tubular arrays. These disturbances of the natural killer cell population seemed to be unrelated to the clinical stage of HIV infection. Despite the importance of interferons and interleukin-2 in the differentiation of natural killer cells ${ }^{50}$ no clear association between low natural killer cell activity and an abnormal production of interferon or interleukin-2 was found. In another study $^{51}$ normal binding of natural killer cells to their targets but a defective killing of attached tumour cells were shown in HIV infection. Our results were also consistent with defective killing. A low natural killer cell activity corresponded to the existence of immature natural killer cells that were devoid of lysosomal parallel tubular arrays. ${ }^{47}$ Occurrence of immature

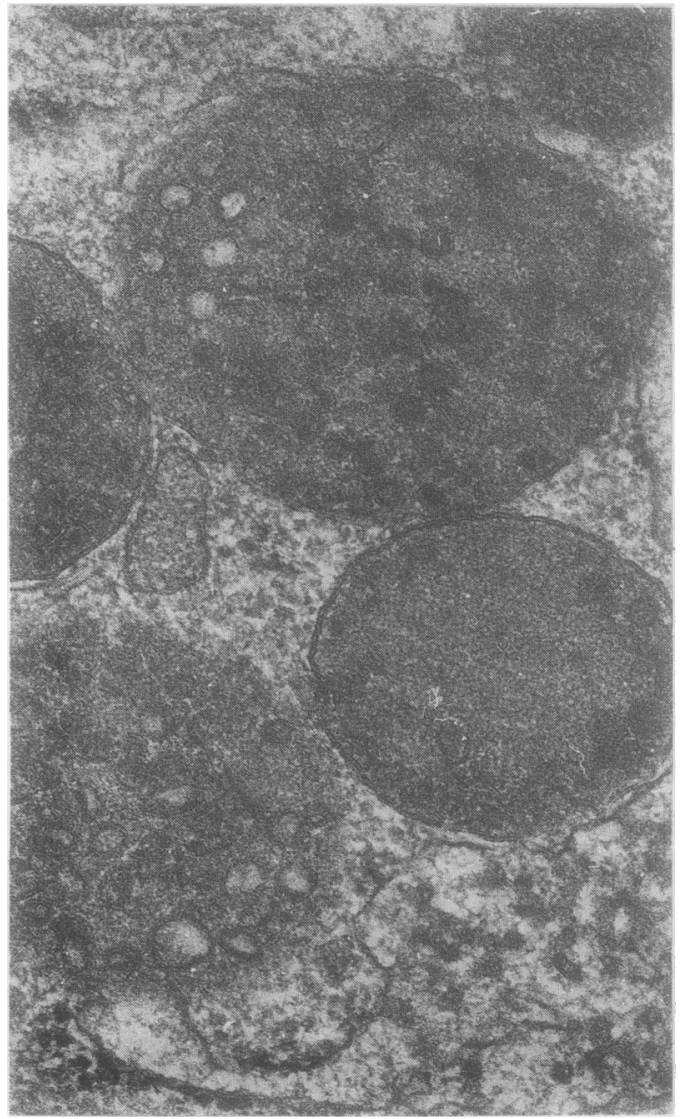

Fig 9 Apparent multivesicular bodies (MVB) in natural killer cell lymphocyte. 


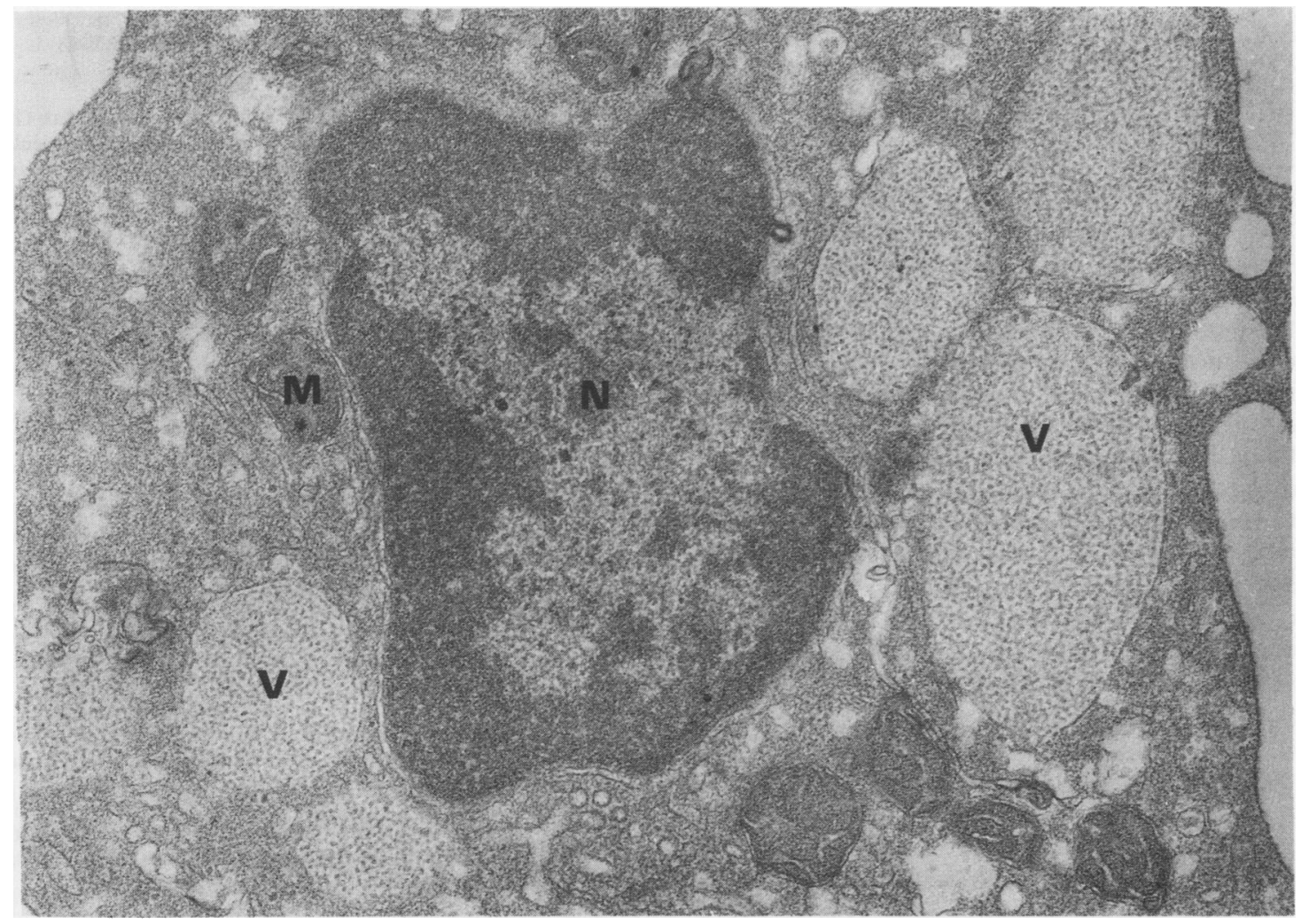

Fig 10 Perinuclear zone of atypical vacuolated lymphocyte. $N=$ nucleus; $M=$ Mitochondria; $V=$ vacuoles.

natural killer cells could be explained by an increased turnover secondary to chronic HIV infection. A direct effect of HIV infection on natural killer cells was not excluded as natural killer cells have already been incriminated in the production of the abnormal acid labile $\alpha$ interferon. ${ }^{52}$

A striking feature was the presence of LAV antigen located in intracytoplasmic vacuoles inside large circulating cells that were sometimes multinucleated. The presence of incomplete intracytoplasmic retrovirus-like particles has been reported previously in fresh peripheral blood cells from a haemophiliac with AIDS. ${ }^{53}$ In this study both anti-p24 against bovine leukaemia virus ${ }^{6}$ and anti-p13 against LAV gave a positive reaction inside these vacuoles. This cross reaction (observed also in the vacuoles of fetal lamb kidney cells infected by bovine leukaemia virus? was probably promoted by the glutaraldehyde fixation (post-embedding immunogold staining method). More recently, Pekovic ${ }^{54}$ also detected HIV antigen by immunofluorescence in peripheral lymphocytes sometimes displaying multinucleated giant forms. Surprisingly, we were unable to identify the membrane phenotype of these vacuolated circulating cells after the pre-embedding immunogold staining technique with anti-HLA DR, OKT4, OKT8, NKH1, and Leu7 monoclonal antibodies. Moreover, in a previous study ${ }^{6}$ no vacuolated giant cells were found in the nonrosetting subset of peripheral mononuclear cells nor in the purified OKT8 positive subset. The hypothesis of a change in the antigenic CD4 site and in the expression of the CD4 molecule in HIV infected cells has been suggested by Klatzmann et al. ${ }^{55}$ The role of the CD4 antigen as a receptor for the gp110 of HIV has been shown. ${ }^{5657}$ During the initial attachment of HIV, the binding of the OKT4a monoclonal antibody seemed to be inhibited but after the production of viral antigens by HIV infected cells the expression of all the CD4 epitopes including OKT4 was found to be depressed $^{5859}$ This last mechanism could underlie the lack of staining of the vacuolated lymphocytes with OKT4 monoclonal antibody.

In conclusion, this immunoultrastructural study of non-cultured circulating lymphocytes from patients infected with HIV allowed us to identify changes which suggest functional disturbances in the natural 
killer cell population. In addition to the presence of possible prognostic ultrastructural markers (tubuloreticular structures, tubular confronting cisternae), the location of HIV antigen was also shown.

We are very grateful to Professors A Burny, JC Chermann, and RC Gallo for the gift of anti-BLV antiserum, anti-LAV antiserum, and $\mathrm{H} 9$ infected cells. We are also grateful to Professors N Dourov, J Diebold,P Dustin, J Flament, P Fondu, J Gilloteaux, P Neve, J J Vanderhaegen, and J Wybran for their constructive criticism. We thank Professor L Thiry and Dr S Sprecher for the lymphocyte cultures and Dr J Cogniaux for the Western blotting analysis. We thank JL Conreur for technical assistance.

Requests for reprints to: Dr W W Feremans, Laboratory of Pathology and Electron Microscopy, Université Libre de Bruxelles, Route de Lennik 808, Bätiment C 10, 1070 Bruxelles, Belgium.

\section{References}

1 Sidhu GS, Stahl RE, El-Sadr W, Zolla-Pazner S. Ultrastructural markers of AIDS. Lancet 1983;i:990-1.

2 Feremans WW, Menu R, Dustin P, Clumeck N, Marcelis L, Hupin $\mathrm{J}$. Virus-like particles in lymphocytes of seven cases of AIDS in black Africans. Lancet 1983;ii:52-3.

3 Anderson MG, Key P, Tovey G, et al. Persistent lymphadenopathy in homosexual men: a clinical and ultrastructural study. Lancet 1984;ii:880-2.

4 Sidhu GS, Stahl RE, El-Sadr W, Cassai ND, Forrester EM, ZollaPazner S. The acquired immunodeficiency syndrome: an ultrastructural study. Hum Pathol 1985;16:377-86.

5 Orenstein JM, Simon GL, Kessler CM, Schulof RS. Ultrastructural markers in circulating lymphocytes of subjects at risk for AIDS. Am J Clin Pathol 1985;84:603-9.

6 Feremans WW, Menu R, Goldman M, et al. Ultrastructural demonstration of retrovirus antigens with immunogold staining in prodromal AIDS. J Clin Pathol 1984;37:1399-403.

7 Thiry L, Sprecher-Goldberger S, Jacquemin P, et al. BLV-related antigens in lymphocytes cultures infected with AIDS-associated viruses. Science 1985;227:1482-4.

8 Centers For Disease Control. Update on AIDS, United States. $M M W R$ 1982;31:507-13.

9 Centers for Disease Control. Revision of the case definition of AIDS for national reporting, United States. Ann Intern Med 1985;103:402-3.

10 Huygen K, Mascart-Lemone F, Cran S, et al. Analysis of the interferon system in African patients with AIDS. Eur $J$ Clin Microbiol 1985;4:304-9.

11 Kirchner H, Kleinicke C, Diegel W. A whole blood technique for testing production of human interferon by leucocytes. J Immunol Methods 1982;48:213-9.

12 Millonig G. Further observations on a phosphate buffer for osmium solutions: In: Breese SS Jr, ed. Proceedings of the Vth international congress for electron microscopy. New York: Academic Press, 1962:8.

13 Luft JH. Improvements in epoxy resin embedding methods. J Cell Biol 1961;9:409-14.

14 Ghadially FN, Senoo A, Fuse Y, Chan KW. A serial section study of tubular confronting cisternae (so-called "test-tube and ringshaped forms") in AIDS. J Submicrosc (ytol 1987;19:175-83.

15 Grimley PM, Decker JL, Michelitch HJ, Frantz MM. Abnormal structures in circulating lymphocytes from patients with systemic lupus erythematosus and related diseases. Arthritis Rheum 1973;16:313-23.
16 Baringer JR. Tubular aggregates in endoplasmic reticulum in herpes simplex encephalitis. $N$ Engl $J$ Med 1971;285:943-5.

17 Hanissian AS, Hashimoto K. Paramyxovirus-like inclusions in rubella syndrome. J Pediatr 1972;81:231-7.

18 Hammar SP, Winterbauer RH, Bockus D, Remington F, Sale GE,

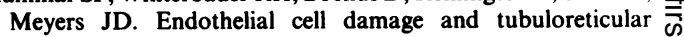
structures in interstitial lung disease associated with collagen vascular disease and viral pneumonia. Am Rev Respir Dis 1983;127:77-84.

19 Schaff Z, Lapis K, Keresztury S, Kollath Z, Herics M, Hollos I. $\overline{\bar{S}}$ Occurrence of tubuloreticular inclusions in acute viral hepatitis. Ultrastruct Res Pathol 1982;3:169-73.

20 Glick AD, Paniker K, Flexner JM, Graber SE, Collins RD. Acute ڤొ leukemia of adults: ultrastructural, cytochemical and histologic $-\overrightarrow{0}$ observations in 100 cases. Am J Clin Pathol 1980;71:459-70.

21 Gyorkey F, Sinkovics JG, Gyorkey P. Electron microscopic observations on structures resembling myxovirus in human $\omega$ sarcomas. Cancer 1971;27:1449-54.

22 Rich SA. Human lupus inclusions and interferon. Science $\frac{\overline{0}}{0}$ 1981;213:772-5.

23 Rich SA, Owens TR, Bartholomew LE, Gutterman JU. Immune $\stackrel{\oplus}{-}$ interferon does not stimulate formation of alpha and beta interferon induced human lupus-type inclusions. Lancet $\mathrm{N}$ 1983;ii:127-8.

24 Kuyama J, Kanayama Y, Katagiri S, Tamaki T, Yonezawa T, 을 Tarui S. Tubuloreticular inclusions and paired cisternae induced in human lymphocytes cultured with staphylococcus aureus Cowan 1. Ultrastruct Res Pathol 1985;8:155-63.

25 Grimley PM, Davis GL, Kang YH, Dooley JS, Strohmaier J, , Hoofnagle JH. Tubuloreticular inclusions in peripheral blood mononuclear cells related to systemic therapy with alpha interferon. Lab Invest 1985;52:638-49.

26 De Stefano E, Friedman RM, Friedman-Kien AE, et al. Acid $\infty$ labile human leukocyte interferon in homosexual men with Kaposi's sarcoma and lymphadenopathy. $J$ Infect Dis 1981;146:451-5.

27 Preble OT, Black RJ, Friedman RM, Klippel JH, Vilcek J. $\bar{\partial}$ Systemic lupus erythematosus: presence in human serum of an unusual acid labile leukocyte interferon. Science 1982; $\frac{\mathrm{O}}{\mathbb{Q}}$ 216:429-31.

28 Jackson D, Tabor E, Gerety RJ. Acute non-A, non-B hepatitis: $\overrightarrow{\vec{O}}$ specific ultrastructural alteration in the endoplasmic reticulum $\frac{O}{3}$ of infected hepatocytes. Lancet 1979;i:1249-50.

29 Shamoto M, Murakami S, Zenke T. A T-cell leukaemia in Japan: an ultrastructural study. Cancer 1981;47:1804-11.

30 Prineas JW. Macrophages, lymphocytes and plasma cells in the perivascular compartment in chronic multiple sclerosis. Lab Invest 1978;38:409-21.

31 Hammar SP, Bockus D, Remington F, Friedman S. More on ultrastructure of AIDS lymph nodes. $N$ Engl $J$ Med 1984;310:924.

32 Yarchoan R, Redfield RR, Broder S. Mechanisms of B cell activation in patients with AIDS and related disorders. J Clin 윽 Invest 1986;78:439-47.

33 Schnittman SM, Lane HC, Higgins SE, Folks T, Fauci AS. Direct $\frac{D}{2}$ polyclonal activation of human B lymphocytes by the AIDS virus. Science 1986;233:1084-6.

34 Lewis WH. Locomotion of lymphocytes. Bull John Hopkins Hosp क 1931;49:29-36.

35 Rich AR, Wintrobe MM, Lewis MR. Differentiation of myeloblasts from lymphoblasts by their manner of locomotion. $\mathrm{W}$ Bull John Hopkins Hosp 1939;65:291-310.

36 Thomas WJ, Yasaka K, Strong DM, Woodruf CM, Stass SA, Schumacher HR. Hand mirror lymphocytes in infectious mononucleosis. Blood 1980;55:925-30.

37 Bernard A, Boumsell L, Bayle C, Micheau C, Penit C, Rouget P. Hand mirror cells in T-cell lymphoma. Lancet 1978;ii:785-6. T

38 Norberg B, Rydgren L, Stenstam M. Amoeboid movement $\bar{O}$ configuration. A cell configuration observed in tumour cells $\overrightarrow{\mathbb{D}}$ from 3 cases of bone marrow neoplasia. Scand J Haematol $\frac{\rho}{\mathbb{D}}$ 1974;12:294-304. 
39 Schumacher HR, Perlin E, Klos JR, Holloway ML, Miller WM, Stass SA. Hand mirror cell leukemia, a new clinical and morphological variant. Am J Clin Pathol 1977;68:531-4.

40 Glassy EF, Sun NCJ, Okun DB. Hand-mirror cell leukemia. Report of nine cases and a review of the literature. Am J Clin Pathol 1980;74:651-6.

41 Schumacher HR, Stass SA, Creegan WJ, Weislow OS. Uropodbearing lymphocytes (hand mirror cells) in a virus-induced murine lymphoma. JNCI 1979;63:1051-5.

42 Stass SA, Phillips TM, Weislow OS, Perlin E, Schumacher HR. Antigen-antibody complexes related to the Baboon endogenous virus in humans with acute lymphoblastic leukemia-hand mirror variant (ALL-HMC). Blood 1980;56:661-6.

43 Schumacher HR, Thomas WJ, Strong M, et al. Acute lymphoblastic leukemia. Hand mirror variant. Viral immune interrelationship as demonstrated by ultrastructural studies. Am J Hematol 1981; 10:399-403.

44 Schumacher HR, Thomas WJ, Creegan WJ, Pitts LL. Infectious mononucleosis and acute lymphoblastic leukemia-hand mirror cells: a qualitative and quantitative ultrastructural study. Am J Hematol 1980;9:67-77.

45 Thomas WJ, Duval-Arnould B, Creegan WJ, Schumacher HR, Forman DS, Strong DM. Morphologic observations of contact-induced lysis of EBV-infected B-lymphocytes by autologous hand mirror T-cells. Am J Hematol 1982;12:109-19.

46 Muse KE, Koren HS. The uropod as an integral and specialized structure of large granular lymphocytes. In: Heberman RB, ed. $N K$ cells and other natural effector cells. New York: Academic Press, 1982:1035-40.

47 Capron F, Perrot JY, Boucheix C, et al. Lysosomal localisation of parallel tubular arrays in chronic lymphocytic leukaemia of T-cell origin: an ultrastructural cytochemical study. J Clin Pathol 1982;35:167-71.

48 Kanayama Y, Hiraoka A, Konishi I, et al. Ultrastructure of normal human T-cell subpopulations. PTA in T-gamma lymphocytes and clustered dense bodies in T-mu lymphocytes. Acta Haematol 1983;70:220-8.
49 Grossi CE, Zicca A, Leprini A, et al. Granule formation in large granular lymphocytes (LGL). Ultrastructural and cytochemical studies on cells from patients with abnormally expanded LGL populations. J Submicrosc Cytol 1984;16:759-71.

50 Riccardi C, Giampetri A, Migliorati G, Cannarile L, D'Adamio L, Herberman RB. Generation of mouse NK cell activity: effect of IL-2 and interferon on the in vivo development of NK cells from bone marrow progenitor cells. Int J Cancer 1986;38:553-62.

51 Katzmann M, Lederman M. Defective postbinding lysis underlies the impaired NK activity in factor VIII-treated, HTLV-III seropositive hemophiliacs. J Clin Invest 1986;77:1057-62.

52 Preble OT, Friedman RM. Interferon-induced alterations in cells: relevance to viral and non-viral diseases. Lab Invest 1983; 49:4-18.

53 Palmer EL, Ramsey RB, Feorino PF, et al. HTLV in lymphocytes of two hemophiliacs with the AIDS. Ann Intern Med 1984;101:293-7.

54 Pekovic DD, Chausseau JP, Lapointe N, et al. Detection of HTLV III/LAV antigens in peripheral blood lymphocytes from patients with AIDS. Archives of Virology 1986;91:11-9.

55 Klatzmann D, Barre-Sinoussi F, Nugeyre M-TH, et al. Selective tropism of LAV for helper-inducer T-lymphocytes. Science 1984;225:59-63.

56 Dalgleish AG, Beverley PCL, Clapham PR, Crawford DH, Greaves MF, Weiss RA. The CD4 (T4) antigen is an essential component of the receptor for the AIDS retrovirus. Nature 1984;312:763-7.

57 McDougal JS, Kennedy MS, Sligh JM, Cort SP, Mawle A, Nicholson JKA. Binding of HTLVIII/LAV to T4 + T-cells by a complex of the $110 \mathrm{~K}$ viral protein and the T4 molecule. Science 1986;231:382-5.

58 Sattentau QJ, Dalgleish AG, Weiss RA, Beverley PCL. Epitopes of the CD4 antigen and HIV infection. Science 1986;234: 1120-3.

59 Hoxie JA, Alpers JD, Rackowski JL, et al. Alterations in T4(CD4) protein and $m$ RNA synthesis in cells infected with HIV. Science 1986;234:1123-7. 